\title{
Simulation and Performance Test Giromill Type Wind Turbine; Case Study Muara Enim, South Sumatra, Indonesia
}

\author{
Ovi Irawan ${ }^{1}$, Yohandri Bow ${ }^{2}$, RD Kusumanto ${ }^{3}$ \\ ${ }^{1}$ Applied Master of Renewable Energy Engineering, Politeknik Negeri Sriwijaya, Palembang, Indonesia \\ ${ }^{1}$ Maintenance Department, PT Bukit Asam,Tbk. Tanjung Enim, Indonesia \\ ${ }^{2}$ Chemical Engineering Department, Energy Engineering Study Program, Politeknik Negeri Sriwijaya, \\ Palembang, Indonesia \\ ${ }^{3}$ Electrical Engineering Department, Politeknik Negeri Sriwijaya, Palembang, Indonesia
}

\section{Keywords:}

Wind energy

Giromill

Simulation

Performance Test

Muara enim

\section{Article Info \\ Article history: \\ Received July 11, 2021 \\ Revised August 10, 2021 \\ Accepted August 20, 2021}

ABSTRACT

This research examines the dynamic load resistance of the Giromill type wind turbine to the variable wind speed, which is converted to the value of the force received by the wind turbine blades. The analysis was carried out numerically using Autodesk Inventor Professional 2019 software. The variations in wind speed used were $2.5 \mathrm{~m} / \mathrm{s}$ with a force value of $0.195 \mathrm{~N}$ for the Giromill turbine, at a speed of $3.5 \mathrm{~m} / \mathrm{s}$ with a force value of $0.274 \mathrm{~N}$, at $4.5 \mathrm{~m} / \mathrm{s}$ with a Force value of $0.352 \mathrm{~N}$ and a wind speed of $5.5 \mathrm{~m} / \mathrm{s}$ with a force rating of $0.430 \mathrm{~N}$. From the simulation results using the Autodesk Inventor Pro 2019 software, the effect of gravitational force is greater than the wind force in, so stress analysis is mainly caused by gravity while the wind force has no significant impact. The simulation results also have a characteristic that the higher the wind speed, the lower the stress value. In addition to the dynamic load simulation, the author also tries to implement the Giromill wind turbines in Muara Enim district, South Sumatra, Indonesia. The wind turbine blade rotation will be faster, and the Wind Generator will produce a greater voltage if it is supported by sufficient wind speed.
\end{abstract}

This is an open access article under the CC BY-SA license.

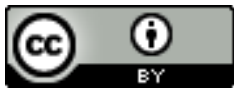

\section{Corresponding Author:}

Yohandri Bow,

Department of Chemical Engineering, Energy Engineering Study Program,

Politeknik Negeri Sriwijaya,

Jl. Srijaya Negara Bukit Besar., Palembang City 30139, South Sumatera, Indonesia

Email: yohandri@polsri.ac.id

\section{INTRODUCTION}

Electricity needs in various regions of the world, especially developing countries, are still predominantly sourced from fossil fuels such as coal and oil. However, the energy transition to a low-carbon energy system with the use of renewable energy has become a global agenda and trend in the framework of mitigating climate change, promoting sustainable development, and energy security [1]-[4]. The reduced production of fossil energy, especially oil, and the global commitment to reducing greenhouse gas emissions, has encouraged the Government to continuously increase the role of new and renewable energy as part of maintaining energy security and independence. According to PP No. 79 of 2014 concerning National Energy Policy, the target for the new and renewable energy mix in 2025 is at least $23 \%$ and $31 \%$ in 2050 . Indonesia has a large enough potential for new and renewable energy to achieve the primary energy mix target, as shown in Table 1 Renewable Energy Potential [5]-[8], [26]-[28]. 
New and Renewable Energy (RE) is a non-fossil energy source that is environmentally friendly and has a vital role because of its contribution in reducing climate change and global warming given its low emission and sustainable nature. However, fossil energy is still dominating the use of domestic energy, and $\mathrm{RE}$ is only an alternative energy source. Even though Indonesia has the potential for renewable energy resources that are relatively large that can be utilized, one of which is the use of wind energy [9]-[13].

Table 1. Renewable Energy Potential [1]

\begin{tabular}{cc}
\hline Energy Type & Potential \\
\hline Hydropower & $94.3 \mathrm{GW}$ \\
Geothermal & $28.5 \mathrm{GW}$ \\
Bioenergy & PLT Bio : $32.6 \mathrm{GW}$ dan BBN : 200,000 Bph \\
Sun & $207.8 \mathrm{GWp}$ \\
Wind & $60.6 \mathrm{GW}$ \\
Ocean Energy & $17.9 \mathrm{G}$ \\
\hline
\end{tabular}

The Government's policies, which continuously encourage EBT, will significantly contribute to increasing energy security. EBT is also considered to be more friendly to the environment because it can reduce the impact of climate change and global warming and has the prospect of sustainability so that public acceptance of the development of the Wind Power Plant (PLTB) development is very positive [14]-[18].

Based on wind prospecting data, Muara Enim District, the research area in South Sumatra, has an average wind speed of $3.4 \mathrm{~m} / \mathrm{s}$ throughout the year, as shown in Fig. 1 [1].
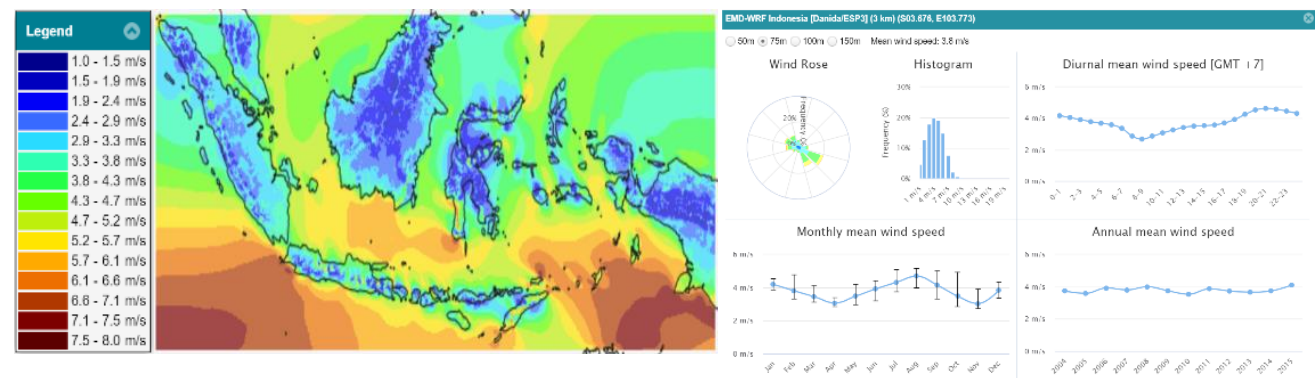

Figure 1. Average Wind Speeds in Kelurahan Air Lintang Muara Enim (Resource: Indonesia.windprospecting.com)

Fig. 1 illustrates the average wind speeds in Kelurahan Air Lintang Muara Enim. This data is used to try to make a simulation with variation wind speed by using Autodesk Inventor Pro 2019.

\section{RESEARCH METHOD}

The design of this study used the Giromill type vertical axis wind turbines. This research will be conducted under the actual conditions. The vertical wind turbine Giromill will be installed on a tower with a height of 2.2 meters and placed on a residential building as high as 5 meters above ground level. Illustration of wind turbine installation at the research location (Fig 2). Besides analyzing the resistance of turbine blades to dynamic loads using the Professional Inventor 2019 software, it is expected that the simulation results are the effectiveness of the types of turbine blades. 


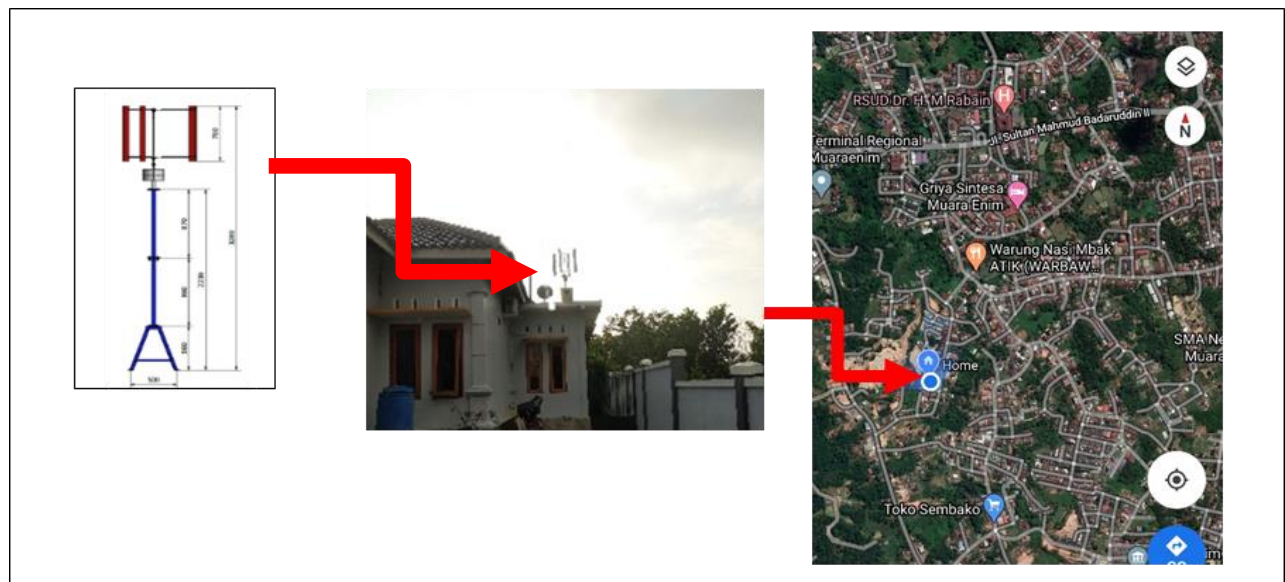

Figure 2. Research Location in Muara Enim Regency (South Sumatera, Indonesia)

From Figure 2, it shows the components of the Giromill type wind turbine and their functions: 1. Giromill blades, serve to catch the wind that converts mechanical energy into kinetic energy.

2. Rotor, serves for the blade construction holder connected to the generator

3. Wind Generator, serves as electronic equipment that converts mechanical energy into electrical energy.

4. Tower, serves as the main tower or wind turbine construction.

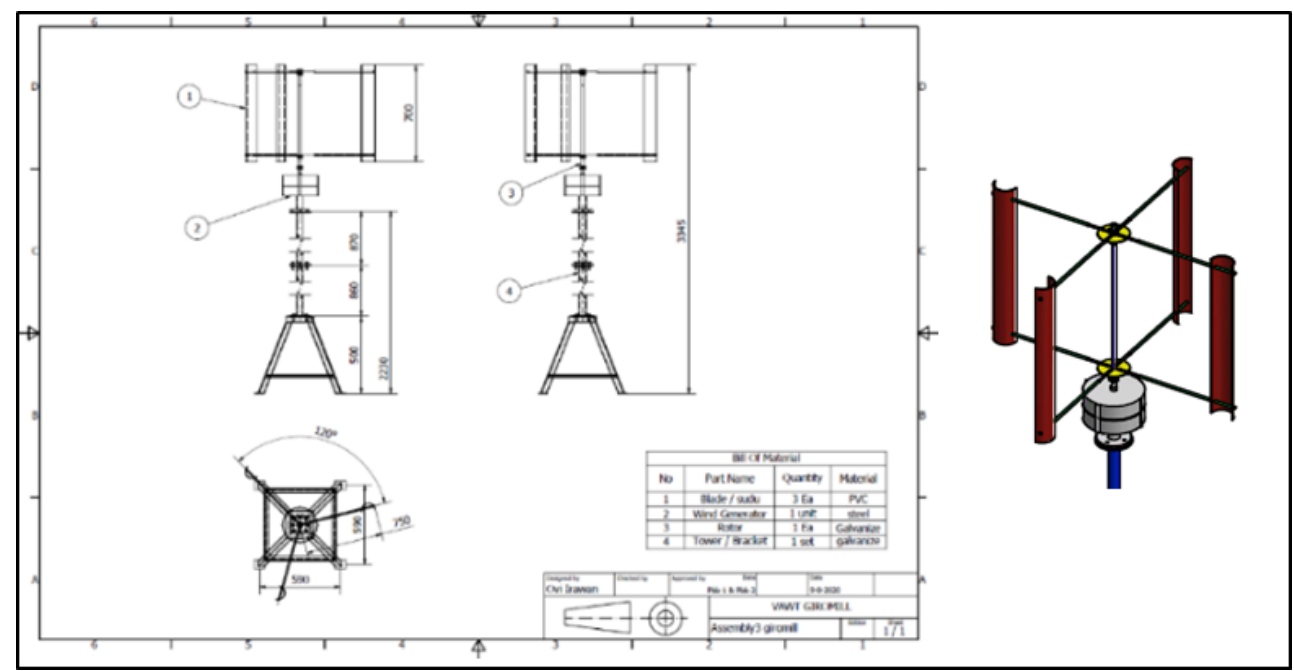

Figure 3. Design of Giromill Wind Turbine

Figure 3 illustrates that the Giromill blade uses PVC pipe material with a diameter of 4" and a length of $700 \mathrm{~mm}$. The turbine blades are connected to the rotor using galvanized pipe material with a diameter of $20 \mathrm{~mm}$ and a mild steel plate with a thickness of $2 \mathrm{~mm}$. 


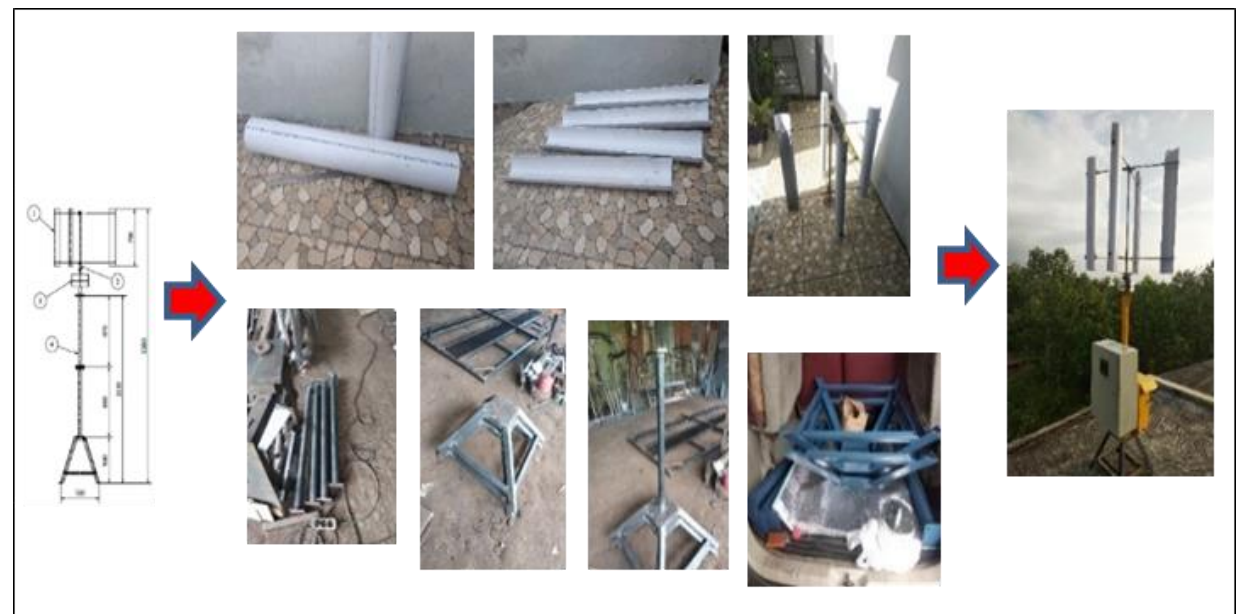

Figure 4. Fabrication Process of Giromill Wind Turbine

In this study, the wind turbine was built on a 2.2 meter high tower with a diameter of $2 "$. The tower construction is made portable, making it easier to move locations on the Residential Building (Figure 4). Because the construction uses segments, it is possible to increase the tower height.

This study aims to get an analysis of the strength of the Giromill Wind Turbine Blade. This research examines the dynamic load resistance of the Giromill type wind turbine to the variable wind speed, which is converted to the value of the force received by the wind turbine blades. The analysis was carried out numerically using Autodesk Inventor Professional 2019 software [29],[30]. The conversion of wind speed to the value of the force can be done using the equation:[19]

$$
F=C p \frac{1}{2} \rho A v^{2}
$$

Force Value converted from the Wind speed Force $(\mathrm{N}), \boldsymbol{\rho}$ is air density $\left(1.225 \mathrm{~kg} / \mathrm{m}^{3}\right), \mathbf{C p}$ is power coefficient (0.4), A is turbine swept area $\left(\mathrm{m}^{2}\right)$, and $\mathrm{v}$ is wind velocity $(\mathrm{m} / \mathrm{s})$.

\section{RESULTS AND DISCUSSION (10 PT)}

This simulation examines the dynamic load resistance of the Giromill wind turbine to the variable wind speed, which is converted to the value of the force received by the wind turbine blades. The analysis was carried out numerically using Autodesk Inventor Professional 2019 software. In this simulation, variations in wind speed were used, namely $2.5 \mathrm{~m} / \mathrm{s}, 3.5 \mathrm{~m} / \mathrm{s}, 4.5 \mathrm{~m} / \mathrm{s}$, and wind speed of $5.5 \mathrm{~m} / \mathrm{s}$. The simulation of these types of wind turbine blades uses PVC for the Giromill turbine blade material. The mechanical properties are shown in the following Table 2.

Table 2. Physical properties of the Giromill Turbine Blade Material (PVC)

\begin{tabular}{ll}
\hline Material & Giromill (PVC) \\
\hline Density & $1.4 \mathrm{~g} / \mathrm{cm}^{3}$ \\
Mass & $0.26 \mathrm{~kg}$ \\
Area & $249936 \mathrm{~mm}^{2}$ \\
Volume & $185152 \mathrm{~mm}^{3}$ \\
Yield Strength & $46.5 \mathrm{MPa}$ \\
Ultimate Tensile Strength & $52.3 \mathrm{MPa}$ \\
\hline
\end{tabular}

Based on the results of the Stress Analysis of the Autodesk Inventor Pro Software. 2019 was obtained as following Table 3 . 
Table 3. Stress analysis at variations Wind Speed

\begin{tabular}{|c|c|c|c|c|c|c|c|c|}
\hline & \multicolumn{2}{|c|}{$5.5 \mathrm{~m} / \mathrm{s}$ wind speed } & \multicolumn{2}{|c|}{$4.5 \mathrm{~m} / \mathrm{s}$ wind speed } & \multicolumn{2}{|c|}{$3.5 \mathrm{~m} / \mathrm{s}$ wind speed } & \multicolumn{2}{|c|}{$\begin{array}{l}2.5 \mathrm{~m} / \mathrm{s} \text { winc } \\
\text { speed }\end{array}$} \\
\hline & Min & Maks. & Min & Maks. & Min & Maks. & Min & Maks. \\
\hline $\begin{array}{l}\text { Von Mises } \\
\text { Stress(Mpa) }\end{array}$ & 0 & 11.35 & 0 & 11.31 & 0 & 11.27 & 0 & 11.21 \\
\hline $\begin{array}{l}\text { Displacement } \\
(\mathrm{mm})\end{array}$ & $0 \mathrm{~mm}$ & 0.555746 & 0 & 0.555265 & 0 & 0.5554862 & 0 & 0.554433 \\
\hline Safety Factor(ul) & 15 & 15 & 15 & 15 & 15 & 15 & 15 & 15 \\
\hline
\end{tabular}

Table 3 shows the analysis of PVC material stress on wind speed variations that have been converted to the force value received by the turbine blade. Table 3 shows that PVC material is safe enough to withstand dynamic loads because the value of the safety factor required for the material to withstand dynamic loads is 2-3. To more easily illustrate the stress analysis on wind speed variations, it can be seen in Figure 5.

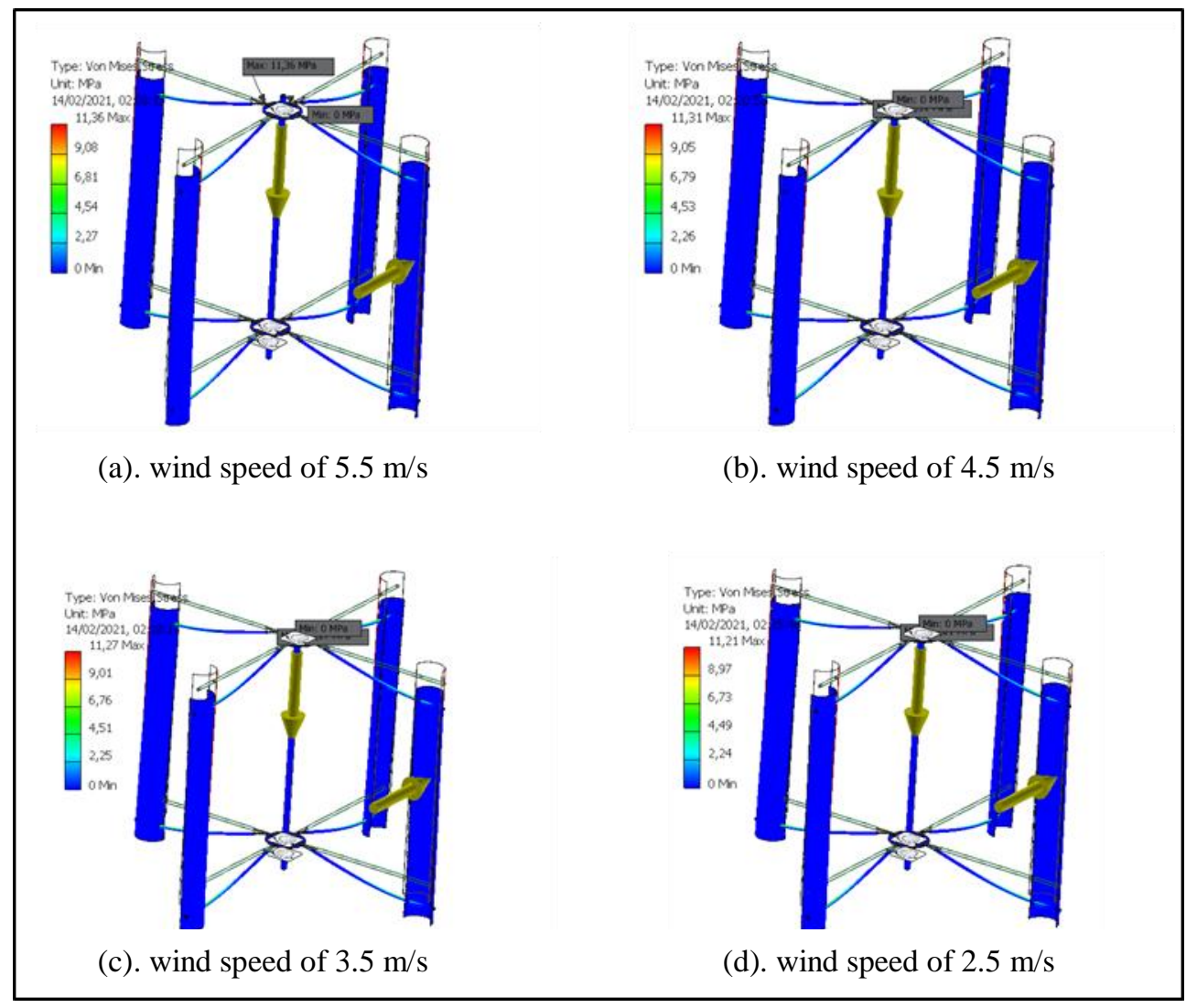

Figure 5. Von Misses stress on the Giromill Type wind turbine blades at variations wind speed

From Figure 5, it can be seen in the simulation, variations in wind speed are converted into force values and how they affect the resistance of the turbine blades. Variations in wind speed from $5.5 \mathrm{~m} / \mathrm{s}, 4.5$ $\mathrm{m} / \mathrm{s}, 3.5 \mathrm{~m} / \mathrm{s}$, and $2.5 \mathrm{~m} / \mathrm{s}$ have no significant effect on the blades because the value of the force received over the turbine blades is smaller than the gravitational force. Besides that, the safety factor of PVC material is also still above the required value of 2-3 so that the turbine blade material is suitable, effective, and safe to implement. From the simulation, it can be seen that the range of von misses voltage values is between 011.36 MPa for a wind speed of 5.5 m/s; 0-11.31 MPa for wind speed 4.5 m/s; 0-11.27 MPa for a wind speed of $3.5 \mathrm{~m} / \mathrm{s}$ and $0-11.21$ for a wind speed of $2.5 \mathrm{~m} / \mathrm{s}$ which are shown in blue to red. An indication of a safe condition is shown in blue.

Simulation and Performance Test Giromill Type Wind Turbine; Case Study Muara Enim, South Sumatra, Indonesia 
Based on the simulation analysis results, the author tries to implement the manufacture of a turbine blade in a residential in the Muara Enim area, South Sumatra, Indonesia. Giromill Wind Turbine Performance test took the wind turbine data and wrote the results in a table $12^{\text {th }}$ of December 2020 starting at 08.00 WIB until 18.00 WIB with time intervals every 30 minutes. The Research result vertical axis wind turbine Giromill type, it can be seen from Fig. 6.

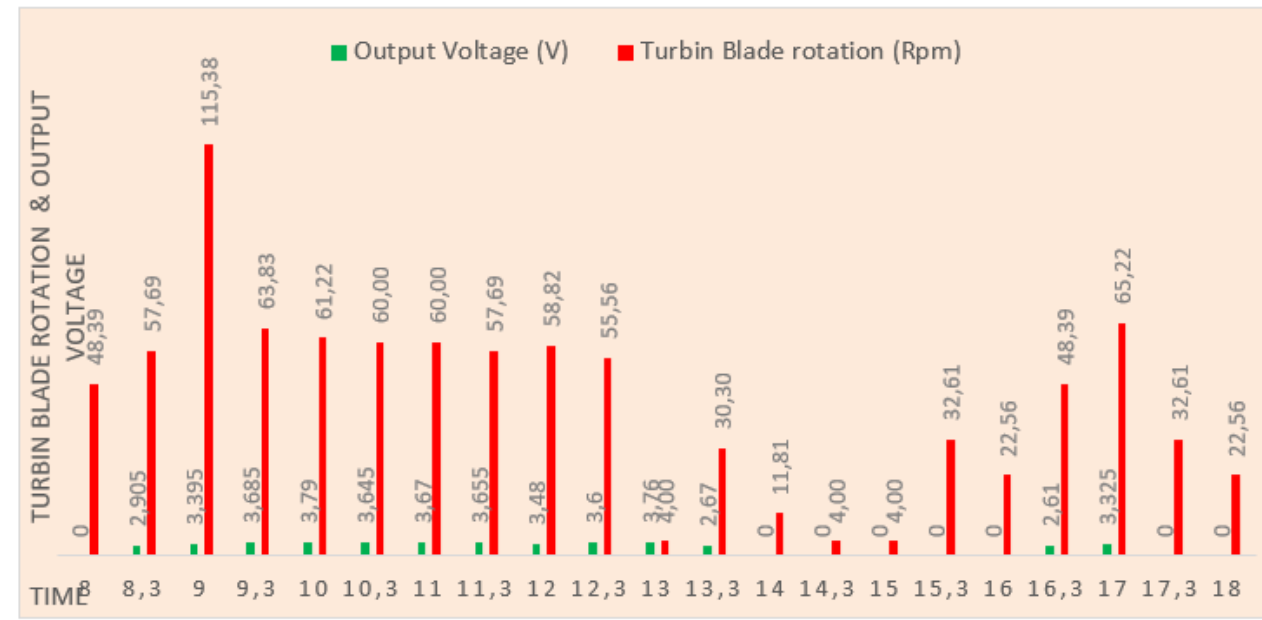

Figure 6. Turbine rotation (rpm) VS voltage (volts) of Giromill wind turbines

From Figure 6, the maximum rotation of the wind turbine can be seen at $78.9 \mathrm{rpm}$ and produces a voltage of 3.76 volts, while the lowest turbine rotation of $34.88 \mathrm{rpm}$ can produce an electrical voltage of 2.61 Volts. The resulting voltage is unstable and always fluctuates depending on the turbine rotation very much, the higher the turbine rotation, the greater the voltage generated.

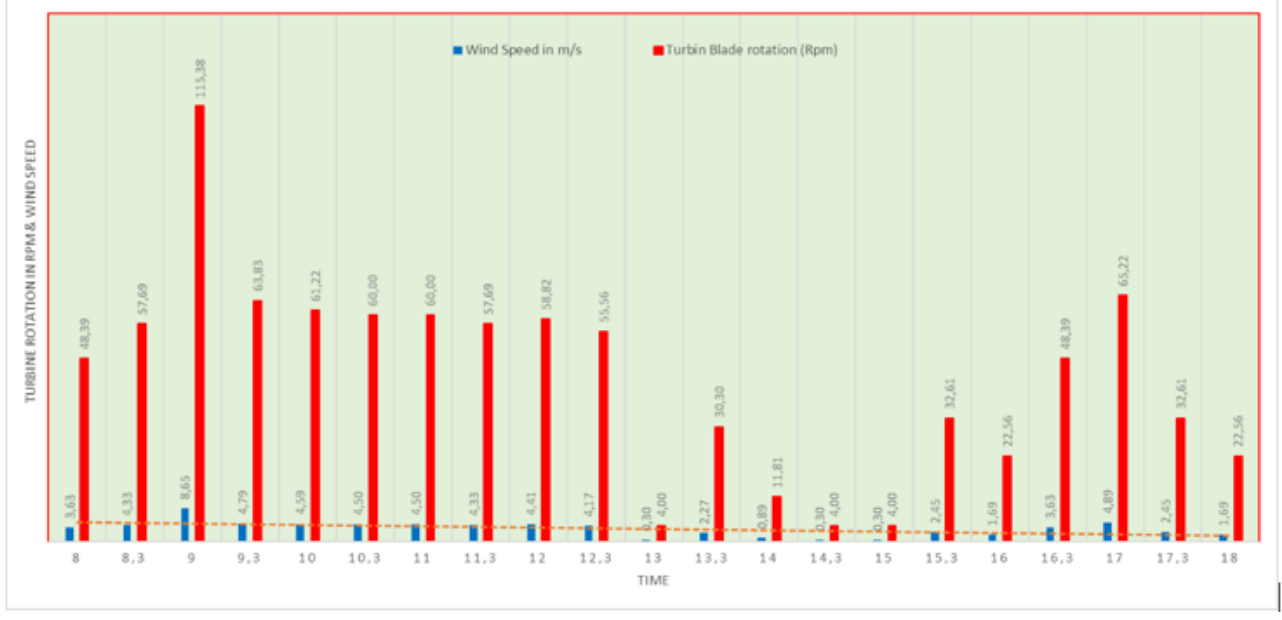

Figure 7 Wind speed in $\mathrm{m} / \mathrm{s}$ vs turbine rotation in rpm of Giromill wind turbines

From Figure 7, the maximum turbine rotation obtained is $115.38 \mathrm{rpm}$ at a wind speed of $8.65 \mathrm{~m} / \mathrm{s}$ and the lowest turbine rotation is $4 \mathrm{rpm}$ at a wind speed of $0.4 \mathrm{~m} / \mathrm{s}$. The graph above shows that the turbine rotation is very dependent on the wind speed. The higher the wind speed, the higher the turbine rotation too.

\section{CONCLUSION}

In the simulation using Autodesk Inventor Pro 2019 software, the effect of gravitational force is greater than the wind force in the Giromill type turbine blade, so stress analysis is mainly caused by gravity while the wind force has no significant effect. The simulation results also have a characteristic that the higher the wind speed, the lower the stress value. In this condition, it can be concluded that the turbine blades are 
still effective in terms of resistance to wind forces. Based on the Giromill type wind turbine graph, the wind turbine rotation, the value of the voltage, and the current generated depends on the wind speed. The wind turbine blade rotation will be faster, and the Wind Generator will produce a greater voltage if it is supported by sufficient wind speed.

\section{ACKNOWLEDGEMENTS}

The authors would like to express deep gratitude to PT Bukit Asam Tbk and Politeknik Negeri Sriwijaya for supporting this research.

\section{REFERENCES}

[1] Institute for Essential Service Reform, "Buletin Strategic Partnership Green and Inclusive Energy," Jakarta, November 2019.

[2] Sekretariat Jenderal Dewan Energi Nasional, "Ketahanan Energi Indonesia,” Dewan Energi Nasional,Jakarta, 2019. (in Indonesian).

[3] Sekretariat Jenderal Dewan Energi Nasional, ISSN 2527 3000, “Outlook Energi Indonesia 2019," Dewan Energi Nasional,Jakarta, 2019. (in Indonesian).

[4] R. Ploetz, R. Rusdianasari, E. Eviliana, "Renewable Energy: Advantages and Disadvantages," Proceeding Forum in Research, Science, and Technology (FIRST), 2016.

[5] Y Bow, T Dewi, A Taqwa, Rusdianasari, Zulkarnain, "Power Transistor 2N3055 as a Solar Cell Device," International Conference on Electrical Engineering and Computer Science (ICECOS), IEEE, 2018.

[6] A. Kurniawan, A. Taqwa, Y. Bow, "PLC Application as an Automatic Transfer Switch for on-grid PV System; Case Study Jakabaring Solar Power Plant Palembang,” J. Phys.: Conf. Ser. 1167 012026, 2019.

[7] S Widodo, A Taqwa and R Rusdianasari, "Solar panels output optimization using Phase Change Material (PCM) and heatsink applied in open-pit mining," IOP Conf. Series: Materials Science and Engineering 1073 (2021) 012041, 2021.

[8] Mirdiansyah, A. Taqwa, Y. Bow. "Monitoring Depth of Discharge of a Valve Regulated Lead Acid Battery in a Standalone PV System," Proceedings of the 4th Forum in Research, Science, and Technology (FIRST-T1-T22020), 2021

[9] T.M. Letcher, "Wind Energy Engineering," A Handbook for Onshore and Offshore Wind Turbines. Elsevier, 2017.

[10] M.M.A. Bhutta, N. Hayat, A. U. Farooq, Z. Ali, Sh. R. Jamil, Z. Hussain, "Vertical Axis Wind Turbine- A Review of Various Confiugations and Design Techniques" Elsevier Ltd. 2011

[11] B.A. Dwiyantoro, V. Suphandani, Rahman, "Studi Eksperimental tentang Karakteristik Turbin Angin Sumbu Vertikal Jenis Darrieus - Savonius," Proceeding Seminar Nasional Tahunan Teknik Mesin XIV (SNTTMXIV), 2015. (in Indonesian)

[12] A. Taqwa, R. Rusdianasari, Budiman, RD. Kusumanto, T. Dewi, "Synchronization and application of IoT for on grid hybrid PV-wind system," International Conference on Applied Science and Technology (iCAST) IEEE 617$621,2018$.

[13] M. Latif, "Efisiensi Prototipe Turbin Angin Savonius pada Kecepatan Angin Rendah," Universitas Andalas Padang. Jurnal Rekayasa Elektrika, 2013. (in Indonesian).

[14] S. Mathew, "Wind Energy Fundamental, Resource Analisys and Economic," Faculty of Engineering. KCAET. Tavanur India. 2006.

[15] E. Hau, "Wind Turbines Fundamentals, Technologies, Application, Economics," Springer. Germany. 2006.

[16] I.P. Prakoso, P.Hartono, U.Lesmana, "Perencanaan Turbin Angin Sumbu Vertikal Tipe Darrieus-H dengan penambahan 2 Blade Savonius untuk Pembangkit Listrik" FTUIM (in Indonesian)

[17] R. B. Yuliandi, Rusdianasari, T. Dewi, "Comparison of blade dimension design of a vertical wind turbine applied in low wind speed," In proceeding of E3S Web of Conference EDP Science, Vol. 68, 2018.

[18] R. Gupta, A. Biswas, K.K. Sharma, "Comparative study of a three-bucket Savonius rotor with a combined threebucket Savonius - three-bladed Darrieus rotor," Renewable Energy 33 , 2008.

[19] C. Sovanara, F. Firdaus, R. Rusdianasari, "A Review on environmental impact of wind energy," in Proceeding Forum in Research, Science, and Technology (FIRST), 2016.

[20] R. H. Barnes, E. V Morozov, and K. Shankar, "Improved Methodology For Design Of Low Wind Speed Specific Wind Turbine Blades," Compos. Struct., vol. 119, pp. 677-684, 2015.

[21] M. Kalantar, S. M. Mousavi, "Dynamic behavior of a stand-alone hybrid power generation system of wind turbine, microturbine," solar array and battery storage. Appl Energy 2010;87:3051-64.

[22] J. Yen and N. Ahmed, "Improving Safety And Performance Of Small-Scale Vertical Axis Wind Turbines," Procedia Eng., vol. 49, pp. 99-106, 2012

[23] W.T. Chong, S.C. Poh, A. Fazlizan, S.Y.Yip, M.H. Koay, W.P. Hew, "Exhaust Air Energy Recovery System for Electrical Power Generation in Future Green Cities, "International Journal of Precision Engineering and Manufacturing, 14(6): p. 1029-1035, 2013.

[24] M.H. Mohamed, A.M. Ali, A.A. Hafiz, "CFD Analysis for H-Rotor Darrieus Turbine As A Low Speed Wind Energy Converter”, Engineering Science and Technology, an International Journal 18, 2015. 
[25] R.Hassanzadeh, M. Mohammadnejad., "Effects of inward and outward overlap ratios on the two-blade Savonius type of vertical axis wind turbine performance". International Journal of Green Energy, 2019.

[26] Y. Bow, A. Syakdani, M. Taufik, and Rusdianasari, "Effect of Drying Ariflow Rate on $\mathrm{H}_{2} \mathrm{O}$ Mass Evaporated on Banana Chips Drying using Photovoltaic Solar Panel”, J. Phys.: Conf. Ser. 1500 012015, 2020.

[27] N. Pasaribu, Rusdianasari, and A. Syarif, "Efficiency of 9Kwp Sun Tracking Photovoltaic in Palembang, Indonesia”, IOP Conf. Ser.: Earth Environ. Sci. 347 012129, 2019.

[28] H. Wibowo, Y. Bow, and CR. Sitompul, "Performance Comparison Analysis of Fixed and Solar-Tracker Installed Panel at PV System”, IOP Conf. Ser.: Earth Environ. Sci. 709 012003, 2021.

[29] A. Garmana, F. Arifin, and Rusdianasari, "CFD Analysis for Combination Savonius and Darrieus Turbine with Differences in the Number of Savonius Turbine Blades", 2021 International Conference on Artificial Intelligence and Mechatronics System (AIMS), IEEE, 2021.

[30] A. Susandi, F. Arifin, and Rusdianasari, "Simulation of Diffuser Parameters in the Performance of Horizontal Axis Wind Turbine using Computational Fluid Dynamics”, Technology Reports of Kansai University, Vol. 63(06), 2021.

\section{BIOGRAPHIES OF AUTHORS}

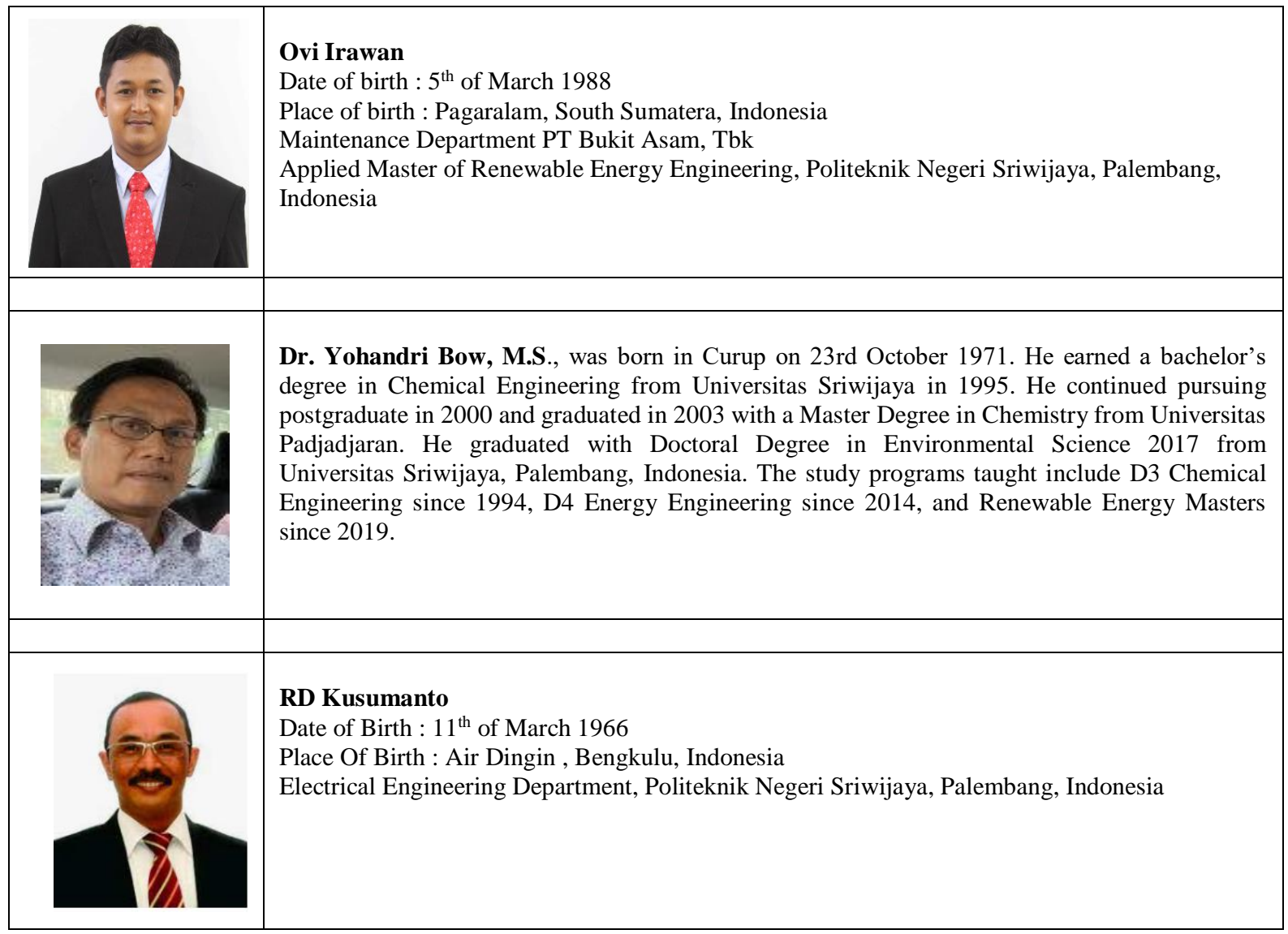

